\title{
PSYCHOMETRICKÉ VLASTNOSTI DOTAZNÍKA KARIÉROVEJ ORIENTÁCIE
}

\author{
Katarína Baňasová \\ Ústav aplikovanej psychológie FSVaZ UKF Nitra \\ kbanasova@ukf.sk
}

\begin{abstract}
Abstrakt: V štúdii sa zameriavame na Dotazník kariérovej orientácie, ktorý identifikuje kariérové kotvy podl'a Scheina. Naším ciel’om je analýza psychometrických vlastností dotazníka. Vzorka pozostávala z 265 stredoškolských študentov. Použili sme Cronbachov koeficient $\alpha$, korigovanú koreláciou položiek a exploračnú faktorovú analýzu. Konštruktovú validitu sme skúmali dotazníkmi VISA (Porfeli, 2011); PVQ (Schwartz, 2001) a CMQ (Abele, Hausman, Weich, 1994). V štúdii sa prikláňame k osemfaktorovému riešeniu dotazníka. Výsledky naznačujú, že by mohlo íst' o validný merací nástroj, avšak zmieňujeme sa o konkrétnych problematických položkách. Odporúčame prihliadat' na špecifiká dotazníka a dotazník d'alej využívat' na výskumné účely.
\end{abstract}

Klúčové slová: Dotazník kariérovej orientácie, kariérové kotvy, reliabilita, konštruktová validita, exploračná faktorová analýza

\section{ÚVOD}

\section{Aktuálna situácia používania metodík v oblasti kariérového poradenstva na stredných školách}

Kariérové poradenstvo v procese druhej smerovej vol'by je nápomocné nielen kvôli vol'be vysokej školy, ale aj pre úspešný prechod študentov do praxe, tzv. school-to-work transition. Zvyšuje sa tak pravdepodobnost' úspechu a záujem o vzdelávanie i rekvalifikovanie. Mladí l'udia by tak mali byt' tiež viac pripravení na zmenu zamestnania, ktorá je v súčasnej situácii na trhu práce bežná (Ihnacík, Špitka, Paulová, 2007).

Možnosti kariérového poradenstva $\mathrm{v}$ školstve sú na Slovensku obmedzené dlhodobým zanedbávaním danej problematiky. Kariéroví poradcovia nie sú dostatočne vybavení spol’ahlivými metodickými nástrojmi, vo svojej praxi používajú metodiky, ktorých spol’ahlivost' je spochybnitel’ná. Na nepriaznivú situáciu v spomínanej oblasti autori upozorňujú dlhšiu dobu (Lepeňová, 2006).

Na Slovensku sú klienti v rámci Centier pedagogicko-psychologického poradenstva a prevencie sledovaní väčšinou iba v oblastiach schopností, osobnosti a záujmov - a to pre nedostatok času, ale aj nedostatok diagnostických nástrojov. Testy schopností sa skracujú a osobnostné testy sa redukujú na používanie $\mathrm{v}$ čo najstručnejšej podobe na rýchle zorientovanie sa v oblasti osobnosti (Gallová, 2013; Ihnacík, 2013).

V predkladanej štúdii sa zameriavame na dotazník, ktorý je medzi výskumníkmi ale aj praktikmi oblúbeným meracím nástrojom, a to Dotazník kariérovej orientácie, ktorý identifikuje kariérové kotvy podl'a Scheinovej Teórie kariérových kotiev. Naším ciel’om je analýza psychometrických vlastností dotazníka- a to reliability a validity, aby sme tak mohli zhodnotit' jeho adekvátnost' používania výskumníkmi aj praktikmi. 
Populáciu, na ktorú sme sa zamerali, tvoria študenti gymnázií, ktorých široký vedomostný a záujmový rozptyl často pri výbere d'alšieho smerovania zneist'uje. Ani bezprostredne pred vol'bou vysokej školy alebo špecifických seminárov nemajú svoje rozhodovanie ukončené.

Teória kariérových kotiev je pomerne tradičný teoretický koncept, ktorý Schein definoval už v roku 1975, ešte stále na Slovensku neexistuje štúdia, ktorá by zist'ovala psychometrické vlastnosti dotazníka a podporila tak používanie dotazníka.

\section{Scheinov koncept kariérových kotiev a jeho vývin}

Pojmom kariérová kotva označuje Schein (1990) subjektívne vnímaný obraz schopností (založený na súčasnom úspechu), obraz potrieb (založený na sebapoznaní, ku ktorému došlo v priebehu minulých situácií a v rámci spätnej väzby od ostatných) a obraz hodnôt a noriem správania (založený na porovnávaní vlastných hodnôt a noriem s hodnotami a normami zdiel'anými v zamestnávatel'skej organizácii). Kariérová kotva predstavuje prvok v predstave človeka o sebe samom, ktorého sa nevzdá ani v prípade, že stojí pred zložitým rozhodovaním. Kariérová kotva sa vyvíja, ked’ človek dostáva zmysluplnú spätnú väzbu (Schein, 1990). Ked’že druhá smerová vol’ba je jedným z dôležitých medzníkov v priebehu kariérovej dráhy človeka, je kariérové poradenstvo na stredných školách kl'účové. Práve preto vnímame za dôležité zamerat' sa práve na populáciu stredoškolských študentov. Gymnaziálny typ školy umožňuje získat' široký rozptyl vedomostí z viacerých vedných odborov, práve preto je táto vol'ba u študentov st’ažená. Sebaobraz vychádza z pochopenia seba samého, ktoré človek získava na základe skúseností v mladosti a v období prípravy na povolanie (Steele, 2009). Práve preto je dôležité pracovat' so študentmi v dostatočnom predstihu, aby kariérová vol'ba bola prirodzeným vyústením úsilia o vol'bu, ktorá je zinternalizovaná a nie je uskutočnená pod časovým tlakom.

Scheinov koncept kariérových kotiev prechádzal postupnou modifikáciou. Schein identifikoval pät' základných kariérových kotiev: kotvu Technicko-funkčnej kompetencie, Manažérskej kompetencie, Autonómie, Istoty, Kreativity a podnikania. Neskôr k piatim základným typom kotiev priradil tri d'alšie, a to kotvu Služby druhým, kotvu Čistej výzvy a kotvu Životnej rovnováhy (1978). Podl'a Scheina (1996) má väčšina l'udí iba jednu dominantnú kariérovú kotvu. Autori však upozorňujú, že jednotlivci môžu mat' viac dominantných kariérových kotiev (Wils, Wils, Trembley, 2010). Súlad s kotvami sa prejavuje predovšetkým vo vyššej výkonnosti pracovníka, vo vernosti súčasnému zamestnaniu a spokojnosti so zamestnaním (Feldman, Bolino, 1996).

Schein vypracoval teóriu kariérových kotiev na základe dlhodobého výskumu. Vo svojej pôvodnej štúdii Schein (1978) sledoval 12-ročnú kariéru 44 bývalých študentov anglickej vysokej školy Sloan School of Management, pričom jeho ciel'om bolo zistit', ako a prečo jednotlivci uskutočnuuú kariérové rozhodnutia (Schein, 2004). Schein identifikuje nakoniec osem kariérových kotiev, ktoré v stručnosti uvedieme tak, ako ich pôvodne uviedol Schein (1990):

Istota/Stabilita- jedinec s ukotvením v istote zostáva dlhodobo v organizácii, v ktorej sa zamestná, je ochotný prispôsobit' sa a plne sa socializovat', rešpektovat' hodnoty a normy organizácie. Nerád cestuje a mení pracovné miesto.

Autonómia- autonómne orientovaní jednotlivci vyhl'adávajú pracovné situácie, v ktorých sú maximálne oslobodení od organizačných obmedzení a prekážok vykonávat' to, $\mathrm{v}$ čom sú profesijne kompetentní. Sú otvorení zmene, aby tak získali ešte väčšiu slobodu.

Manažérska kompetencia- zamestnanci orientovaní na manažérske kompetencie radi dohliadajú, ovplyvňujú a vedú ostatných, ašpirujú na povýšenie na generálneho riaditel'a ako prostriedok na dosiahnutie pocitu úspechu. 
Technicko-funkčná kompetencia- zamestnanci s výraznou technicko-funkčnou orientáciou sa primárne zameriavajú na technický a funkčný obsah práce. Je pre nich prioritné ostat' expertnými vo svojom odbore.

Kreativita a podnikanie- títo l'udia majú potrebu vytvárat' nový produkt alebo službu podl'a seba, a to založením nového vlastného biznisu, ktorý zahŕňa tiež manipuláciu s peniazmi.

Služba/Oddanost'- l'udia, ktorí radi slúžia druhým a snažia sa spravit' svet lepším miestom pre život. Viac sa zaujímajú o prácu, ktorá bude napínat' ich hodnoty než ako zohl'adňovat' ich zručnosti.

Výzva/Sút’až- ide o naplnenie z prekonávania neprekonatel'ných prekážok, riešenia neriešitel'ných problémov a uspokojenia z vít’azstva nad vel’mi schopnou konkurenciou. Takíto l'udia sú vel'mi ciel'avedomí a netolerantní k druhým bez porovnatel'nej ašpirácie.

Životný štýl/Životná rovnováha- Jedinci s túžbou vyvinút' životný štýl, ktorý integruje rodinu, kariéru a vlastný sebarozvoj. Vyhl'adávajú organizácie, ktoré majú silné prorodinné hodnoty.

Izraelskí autori na základe testovania psychometrických vlastností však zastávajú názor o existencii deviatich faktorov dotazníka. Faktor Kreativita a podnikanie delia na dva existujúce faktory: a to na dimenzie Kreativita a Podnikanie (Danziger, Rachman-Moore, Valency, 2007). Existenciu deviateho faktora na základe empirickej verifikácie daného modelu odôvodňujú aj iní autori, tým oponujú samotnému autorovi teórie (DeLong, 1982; Jiang and Klein, 1999; Marshall, Bonner, 2003; Ramakrishna, Potosky, 2003).

Autori novších štúdií rozpracovali teóriu kariérových kotiev v cyklickej štruktúre, a identifikujú významové vzdialenosti medzi jednotlivými kotvami, a tiež ku každej kotve uvádzajú jej antagonistickú verziu (napr. opakom kotvy Služba druhým je Manažérska kotva; graf 1). Iné štúdie delia kotvy pola ciel'a a zámeru, ktorý napíňajú. Ide o kotvy založené na talente (Technickofunkčná kompetencia, Manažérska kompetencia, Kreativita a podnikanie); kotvy založené na potrebách (Autonómia, Istota, Životný štýl) a kotvy založené na hodnotách (Služba druhým, Čistá výzva; Coetzee, 2011).

\section{Dotazník kariérovej orientácie}

Ciel'om Dotazníka kariérovej orientácie je nasmerovat' myšlienky odpovedajúceho k lepšiemu pochopeniu vlastného talentu, motívov a hodnôt. Česká forma dotazníka, ktorá bola uverejnená v manuáli dotazníka (Schein, 2004) obsahuje 40 položiek, pričom respondent hodnotí svoje odpovede v rozsahu štvorbodovej Likertovej škály (1 - nikdy, 2 - niekedy, 3 - zriedka, 4 - vždy).

Aj napriek obl'úbenému používaniu dotazníka vo výskume, ale aj v praxi kariérových poradcov, na Slovensku ešte neboli overované psychometrické vlastnosti dotazníka, dotazník tiež nie je štandardizovaný. V zahraničí však boli overované psychometrické vlastnosti dotazníka, a to rôznymi štúdiami, ktorých vzorka pozostávala prevažne z pracujúcich dospelých (Custido, 2000), ale aj absolventov vysokých škôl (Marshall, Bonner, 2003). Išlo o analýzy na anglickej (Brindle, Whapham, 2003), americkej (Jiang, Klein, 1999), filipínskej (Custido, 2000), tureckej (Costigan, Gurbuz, Sigri, 2016), či izraelskej vzorke (Danziger, Rachman, Moore, Valency, 2008), ktoré potvrdili dobré psychometrické vlastnosti dotazníka.

\section{Dôkazy konštruktovej validity dotazníka}

Samotná spomínaná definícia kariérových kotiev pojednáva o kariérových kotvách ako o súhrne hodnôt, motívov a faktorov sebaobrazu, ktoré nás v danom povolaní stabilizujú. Pri úvahách o hodnotení konštruktovej validity dotazníka sme preto vychádzali z aktuálnej teoretickej 
koncepcie Schwartzovej teórie hodnôt (1992, faktory hodnôt), teórie kariérovej motivácie (faktory motivácie; Abele, Hausman, Weich, 1994) a teórie pracovnej identity (faktory sebaobrazu; Porfeli, 2011).

Mená výskumníkov, ktoré sa spájajú s výskumom hodnotovej orientácie sú Allport, Vernon a Lindzey. Ich teórie však časom zmodernizovali a dostali novú formu v podobe štúdií Schwartza, ktorý namiesto tradičného hierarchického usporiadania hodnôt identifikoval ich cyklickú štruktúru. Najnovšie štúdie konceptu Kariérových kotiev navrhujú práve cyklickú štruktúru, i ked' sa tento prístup potýka s kritikou (Coetzee, Schreuder, 2011). Ked’že teória je validná tiež multikultúrne, zvolili sme si ju ako vhodnú pre dôkazy konštruktovej validity dotazníka. V štúdii Wilsovej, Wilsa a Trembleyho (2010) sa prirovnáva cyklická štruktúra Teórie kotiev k cyklickej štruktúre Schwartzovej teórie hodnôt spôsobom, že jednotlivé kotvy priradzujú do kvadrantov, na ktorých sa cyklickost' teórie hodnôt zakladá (graf 1).

Koncepcia pracovnej identity prešla taktiež svojim dlhodobým vývinom. Na počiatku vznikol koncept ego-identity (Marcia, 1993; Luyckx et al., 2006; Meeus and Crocetti, 2009), ktorá sa neskôr sformovala tiež do podoby Porfeliho Teórie pracovnej identity (Porfeli, 2011).

Zmienené konštrukty by mali byt' natol'ko prepracované a komplexné, že predpokladáme ich potenciál zachytit' očakávané vzt’ahy, a tak prispiet' k identifikovaniu úrovne validity Dotazníka kariérovej orientácie aj na slovenskej populácii.

Graf 1 Prepojenie Schwartzovej kruhovej teórie hodnôt a Scheinovej Teórie kariérových kotiev (podl'a Wils, Wils, Trembley, 2010)

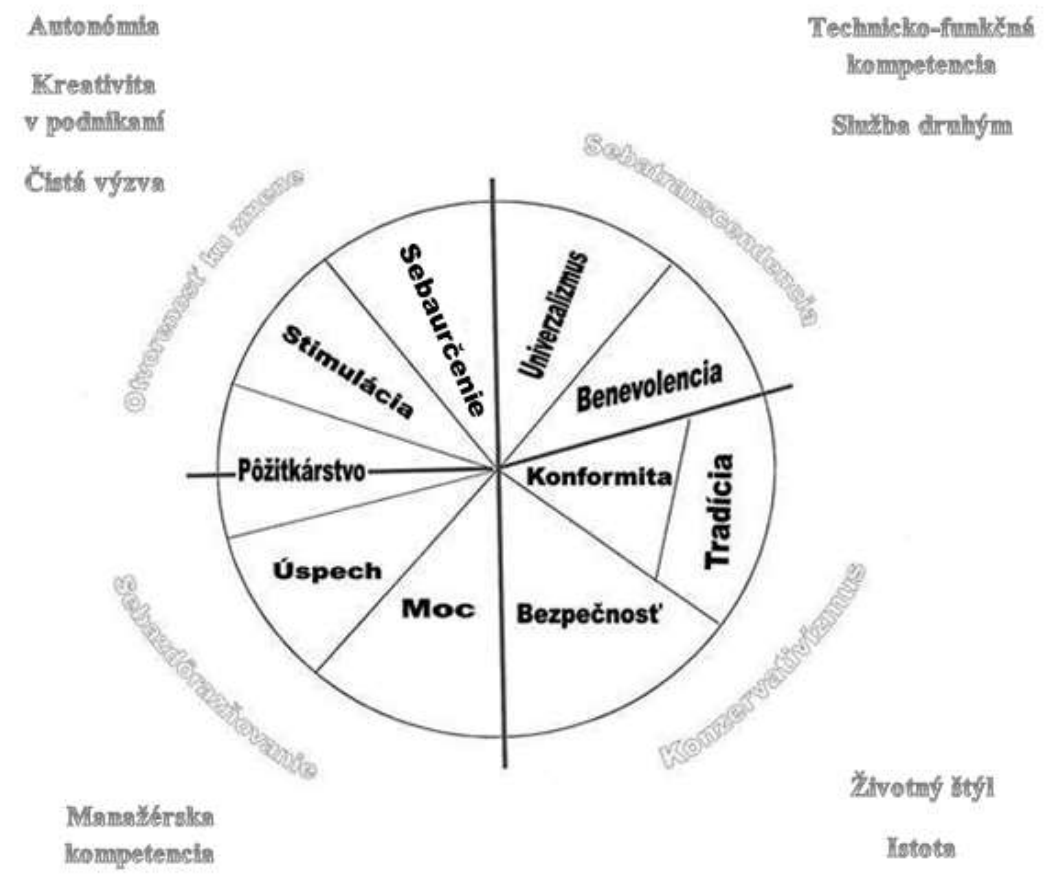




\section{Výskumná vzorka}

Zber dát sa uskutočnil na vzorke gymnazistov prvých až tretích ročníkov. Aj ked' sa Scheinova teória kariérových kotiev zmieňuje o špecifikovaní kariérových kotiev v priebehu pracovnej kariéry a praxe človeka, praktikmi a výskumníkmi je však využívaná aj $\mathrm{v}$ populácii bez pracovných skúseností.

Vzorka pozostávala z 265 študentov (134 žien a 131 mužov); $\mathrm{M}_{\mathrm{vek}}=17,28, \mathrm{SD}_{\mathrm{vek}}=, 77$. Počet výberu respondentov spíňa kritérium vel'kosti vzorky, ktorá má byt' pri prevedení exploračnej faktorovej analýzy, $v$ pomere počet respondentov $\mathrm{k}$ počtu premenných (položiek dotazníka) minimálne 5:1 (Stevens, 2002).

\section{Procedúry}

Verziu dotazníka, ktorá je používaná praktikmi a priamo vychádza z pôvodného manuálu dotazníka, zostaveného Scheinom sa nám podarilo získat' v českom jazyku. Uskutočnili sme preklad do slovenského jazyka s ohl'adom na obsahové zachovanie položiek.

Vnútornú konzistenciu dotazníka sme overovali výpočtom Cronbachovho koeficientu alfa. Previedli sme tiež korigovanú koreláciu položiek, ktorá spočíva v korelácii položiek dotazníka navzájom s hodnotami škál bez danej položky (Hoyle, 2012).

Prevedenie exploračnej faktorovej analýzy dotazníka sme zvolili vzhl'adom na Scheinom navrhovanú 8 - faktorovú štruktúru dotazníka, a vzhl'adom na fakt, že ide o prvú štúdiu na slovenskej vzorke, ktorá sa zaoberá psychometrickými vlastnost'ami dotazníka, a tiež vzhl'adom na fakt, že najnovšie štúdie uvádzajú existenciu dokonca deviatich faktorov. Chceli sme zistit', do akej miery jednotlivé položky prispievajú k celkovému rozloženiu faktorov dotazníka. Rozhodli sme sa pre rotáciu Varimax, ked'že väčšina faktorov by nemala navzájom korelovat' (Hendl, 2004). Overenie nezávislosti faktorov uvádzame vo výsledkoch.

Konštruktovú validitu sme skúmali prostredníctvom dotazníkov, ktoré merajú pracovnú identitu, hodnotovú orientáciu a kariérovú motiváciu. Dotazník VISA (The Vocational Identity Status; Porfeli, 2011) meria najnovšie prepracovaný model kariérovej identity, ktorý objasňuje, nakol'ko jednotlivec pocit'uje k povolaniu záväzok, či dostatočne skúma a pátra po kariérových možnostiach a nakol'ko je k týmto možnostiam otvorený a prehodnocuje ich. Dotazník je primárne určený pre stredoškolákov, ale tiež pre vysokoškolákov v rôznej fáze rozhodovania o kariérovom smerovaní, ked'že meria ich aktuálny status kariérovej identity. Respondent odpovedá na 5-bodovej Likertovej škále. Dotazník meria tri dimenzie, na základe ktorých je možné vymedzit' šest' typov pracovnej identity. Charakter typov pracovnej identity v našej vzorke študentov je podobný pôvodnej americkej vzorke (Baňasová, Sollár, Sollárová, 2016). Zistilo sa, že vnútorná konzistencia škál je adekvátna $(\alpha>0.68)$ a dotazník taktiež vykazuje adekvátnu konštruktovú validitu dimenzií (Baňasová, 2016).

Dotazník PVQ (Portrait Values Questionnaire; Schwartz, 2001) meria hodnotovú štruktúru jednotlivca na základe Schwartzovej teórie hodnôt. Dotazník opisuje 21 charakterov osôb. Úlohou respondentov je určit' na šest'bodovej škále nakol'ko sa na nich samých daná osoba ponáša. Výstupom je skóre kruhovej štruktúry hodnôt prvého a druhého rádu, ktoré sú vo vzájomných rôzne blízkych vzt'ahoch. Dotazník identifikuje desat' základných typov hodnôt: Moc (Power), Úspech (Achievement), Hedonizmus (Hedonism), Stimulácia (Stimulation), Sebaurčenie (Selfdirection), Univerzalizmus (Universalism), Benevolencia (Benevolence), Tradícia (Tradition), Konformita (Conformity) a Bezpečie (Security). Na Slovensku bola sledovaná konštruktová validita nástroja s dobrými výsledkami (Budjačová, 2015; Šnejdrlová, 2015). 
Použili sme tiež dotazník CMQ (Career Motivational Questionnaire; Abele, Hausman, Weich, 1994). Škála pozostáva z 27 položiek. Probant odpovedá na položku, nakol'ko dané tvrdenie preňho platí (Abele, Hausman, Weich, 1994). Škála pozostáva z troch subškál, ktoré merajú intrinzickú motiváciu (je charakterizovaná záujmom a radost’ou z vykonávanej profesijnej aktivity), extrinzickú motiváciu (ktorá je charakterizovaná potrebou po úspechu, prestíži či dobrom plate) a extraprofesionálnu motiváciu (je charakterizovaná uprednostňovaním rodiny, flexibilnými pracovnými hodinami a pracovnou istotou; Buddeberg-Fisher et al., 2008).

Slovenská verzia meracieho nástroja po úprave predstavuje reliabilný a validný merací nástroj overený na vzorke stredoškolských študentov. Prevedenie faktorovej analýzy podporuje navrhovanú 3-faktorovú štruktúru dotazníka (Baňasová, Sollár, 2015).

\section{VÝSLEDKY}

Vnútorná konzistencia pôvodnej verzie dotazníka administrovanej stredoškolským študentom v rámci pôvodných Scheinom navrhnutých škál vykazovala väčšinou uspokojivé hodnoty $\alpha>, 720$, s výnimkou škál Technicko-funkčnej kompetencie $\alpha=, 494$, škály Istoty $\quad \alpha=, 610$ a Životného štýlu $\alpha>, 677$.

Tab.1: Vnútorná konzistencia škál Dotazníka kariérovej orientácie $n=265$

\begin{tabular}{|l|l|}
\hline $\begin{array}{l}\text { Škály Dotazníka } \\
\text { kariérovej orientácie }\end{array}$ & Cronbachova $\boldsymbol{\alpha}$ \\
\hline Istota &, 610 \\
\hline Autonómia &, 768 \\
\hline Manažérska kompetencia &, 720 \\
\hline Technicko-funkčná kompetencia &, 494 \\
\hline Kreativita a podnikanie &, 763 \\
\hline Služba druhým &, 777 \\
\hline Čistá výzva &, 790 \\
\hline Životný štýl &, 677 \\
\hline & \\
\hline
\end{tabular}

Korigovaná položková analýza, na základe dobrých korelačných koeficientov, preukázala vhodnost' všetkých položiek okrem položky 17, ktorá sýti faktor Technicko-funkčnej kompetencie, ktorá korelovala s príslušnou škálou s vylúčením samotnej položky štatisticky nevýznamne. Ostatné položky preukázali štatisticky významné korelácie $(\mathrm{r}=, 312 ; \mathrm{p}<, 05-\mathrm{r}=, 741 ; \mathrm{p}<, 001)$. Po vylúčení položky 17 sa vnútorná konzistencia škály Technicko-funkčnej kompetencie zvýšila $\mathrm{z} \alpha=494$ na $\alpha=590$. Viac sa zmienime o položkovej analýze konkrétne pri problematických položkách v rámci diskusie.

Vhodnost' použitia faktorovej analýzy potvrdila štatistická významnost' Bartlettovho testu sfericity $(\mathrm{p}<0,001)$ a Kaiserova-Mayerova-Olkinova miera adekvátnosti výberu položiek (KMO = ,813). Usúdili sme, že normálne a parciálne korelácie položiek sú významné a použitie faktorovej analýzy má zmysel (Field, 2005; Kaiser, 1974; Stevens, 2002). Rozhodli sme sa pre exploračnú faktorovú analýzu s rotáciou Varimax, ked’že faktory by navzájom nemali korelovat'. Rotáciu Varimax používali aj zahraniční autori v štúdiách, ktoré sa venovali faktorovej štruktúre dotazníka (Igbaria, Greenhaus, Parasuraman, 1991; Crepeau et al., 1992; Igbaria, Baroudi, 1993; 
Jiang, Klein,1999; Custido, 2000; Ramakrishna, Potosky, 2003). Overenie nezávislostí faktorov ukázalo, že medzi faktormi, ktoré spolu štatisticky významne korelujú, je sila korelácií slabá, v niektorých prípadoch v nižších stredných hodnotách $(\mathrm{r}<, 576 ; \mathrm{p}<, 001)$. Túto skutočnost' prisudzujeme aj spoločnej podstate určitých faktorov, ktoré sa podl'a Coetzeeovej (2011) delia aj podl'a základných ciel’ov a záujmov na kotvy, ktoré sú založené na talente, kotvy založené na potrebách a kotvy založené na hodnotách.

Previedli sme exploračnú faktorovú analýzu pri riešení, ktoré zahŕňa neobmedzený počet faktorov, a tiež analýzu s obmedzením na 8 a 9 faktorov. Riešenie s neobmedzeným počtom faktorov generovalo 10 faktorov. Devät'faktorové riešenie sme zvolili na základe výskumov, ktoré zist'ovali psychometrické vlastnosti Dotazníka kariérových kotiev (Marshall, Bonner, 2003; Danziger, Rachman-Moore, Valency, 2007). Autori vychádzajú z presvedčenia, že kotva Kreativita a podnikanie sa môže delit' na osobitné faktory- Kreativita a Podnikanie. Zmienené riešenie sa nám neosvedčilo a príliš nekonzistentné faktorové riešenie nebolo najlepším možným. Ako výstup predkladáme klasické osemfaktorové riešenie podl'a Scheina, ktoré sa ukázalo ako najviac konzistentné.

V rámci škály Istoty sú všetky položky sýtené príslušným faktorom vo vyšších hodnotách ,584 ,697, okrem položky 12, ktorá je sýtená najmä samostatným faktorom, ktorým sú sýtené najmä položky škály Technicko-funkčnej kompetencie.

Subškála Autonómie je konzistentná a s výnimkou položky $38(429)$ sú faktorové nabitia položiek na vyššej úrovni <,663. Položka je tiež sýtená faktorom, ktorý prislúcha k položkám subškály Životný štýl, a to v stredných hodnotách.

Subškála Manažérskej kompetencie vykazuje vyššie nabitia položiek príslušným faktorom <,579 s výnimkou položky 2, ktorá v stredne silnej a zápornej hodnote sýti 7. faktor, ktorý nie je konzistentný a sýtia ho tiež položky 12, 26, 8 a 35.

Škála Technicko-funkčnej kompetencie sa javí ako problematická. Prvá položka sýti 1. faktor v stredných hodnotách, a tiež 8 . faktor v stredných hodnotách v zápornom smere. 1. faktor je sýtený položkami Čistej výzvy, a tiež položkami Služby druhým. Položka 9 sýti prvý faktor v stredne silných hodnotách (,594). Položka 17 silne sýti ôsmy faktor (,729), ktorý nie je konzistentný a zlučuje položky z oblasti Čistej výzvy a Technicko-funkčnej kompetencie. Položka 26 sýti v stredných hodnotách $(, 578)$ siedmy faktor. Položka 35, podobne ako položky 1 a 9, na úrovni ,530 sýti prvý faktor, faktor Služby druhým a Čistej výzvy.

Subškála Služba druhým sýti prvý faktor a podl'a našich výsledkov sa javí ako jednotná s hodnotami faktorových nabití položiek $>, 432$. Avšak, prvý faktor je jednotne sýtený položkami subškály Čistej výzvy, Technicko-funkčnej kompetencie, a tiež položkou 20 spadajúcej do subškály Kreativita a podnikanie.

Subškála Čistá výzva, ktorá je jednotná, avšak významovo neodlíšená od ostatných škál, je až na položku 32 konzistentná. Položka 32 sýti okrem prvého faktora tiež druhý faktor, ktorý spadá k významu subškály Manažérskej kompetencie.

Položky subškály Životný štýl vykazujú stredné hodnoty faktorových nabití >,448. Položky nie sú sýtené ostatnými faktormi, prípadne sú sýtené v nízkych hodnotách <,306.

Položky subškály Kreativita a podnikanie sýtia piaty faktor, a to v dostatočne silných hodnotách $>, 649$, okrem položky 20, ktorá má stredne silné faktorové nabitie v rámci prvého faktora, ktorý zlučuje položky Čistej výzvy, Technicko-funkčnej kompetencie a Služby druhým.

Uvádzame tiež vlastné hodnoty faktorov (Eigenvalues) pri 8-faktorovom riešení a percentá rozptylu pre jednotlivé faktory. Faktory spolu vysvetl'ujú 55,93 \% rozptylu (tab. 2). 
Tab. 2: Faktorová štruktúra položiek pôvodného modelu dotazníka po rotácii, $n=265$ (uvádzame faktorové sýtenie položiek $>0,30$ )

\begin{tabular}{|c|c|c|c|c|c|c|c|c|c|}
\hline \multirow{2}{*}{ Škála } & \multicolumn{9}{|l|}{ Faktor } \\
\hline & Položky & 1 & 2 & 3 & 4 & 5 & 6 & 7 & 8 \\
\hline \multirow{5}{*}{ Istota } & 5 & & &,- 317 & & & ,650 & & \\
\hline & 12 & & & & & & & ,466 & \\
\hline & 19 & & & & ,300 & & ,697 & & \\
\hline & 25 & & & & & & ,744 & & \\
\hline & 37 & & & & & &, 584 & & \\
\hline \multirow{5}{*}{ Autonómia } & 3 & & & ,768 & & & & & \\
\hline & 11 & & &, 726 & & & & & \\
\hline & 18 & & & ,663 & & & & & \\
\hline & 31 & & &, 743 & & & & & \\
\hline & 38 & & &, 429 & ,411 & & & & \\
\hline \multirow{5}{*}{$\begin{array}{l}\text { Manažérska } \\
\text { kompetencia }\end{array}$} & 2 & ,349 & & & & & &,- 423 & \\
\hline & 10 & & ,747 & & & & & & \\
\hline & \begin{tabular}{|l|}
21 \\
\end{tabular} & & 751 & & & & & & \\
\hline & \begin{tabular}{|l|}
21 \\
30
\end{tabular} & & 686 & & & & & & \\
\hline & \begin{tabular}{|l|}
36 \\
\end{tabular} & & 579 & & & & & & \\
\hline \multirow{5}{*}{$\begin{array}{l}\text { Technicko- } \\
\text { funkčná } \\
\text { kompetencia }\end{array}$} & 1 & ,442 & & & & & & &,- 362 \\
\hline & 9 &, 594 & & & & & & & \\
\hline & 17 & & & & & & & & ,729 \\
\hline & 26 & & & & & & &, $\mathbf{5 7 8}$ & \\
\hline & 35 &, 530 & & & & & & ,381 & \\
\hline \multirow{5}{*}{$\begin{array}{l}\text { Služba } \\
\text { druhým }\end{array}$} & 7 & ,717 & & & & & & & \\
\hline & 14 & ,639 & & & & & & & \\
\hline & 22 & ,760 & & & & & & & \\
\hline & 28 & ,731 & & & & & & & \\
\hline & 34 & 432 & & & ,316 & & & ,386 & \\
\hline \multirow{5}{*}{ Čistá výzva } & 8 & ,682 & & & & & & & \\
\hline & 15 & ,717 & & & & & & & \\
\hline & 23 & ,501 & & & & & & & 372 \\
\hline & \begin{tabular}{|l|}
32 \\
\end{tabular} & 450 & ,453 & & & & & & \\
\hline & 40 &, 549 & & & & & & & ,336 \\
\hline \multirow{5}{*}{ Životný štýl } & 6 & & & & ,657 & & & & \\
\hline & 16 & & & & ,653 & & & & \\
\hline & 24 & & & &, 575 & & & & \\
\hline & 27 & &,- 446 & & ,448 & & & ,306 & \\
\hline & 39 & & & & ,651 & & & & \\
\hline \multirow{5}{*}{$\begin{array}{l}\text { Kreativita } \\
\text { a podnikanie }\end{array}$} & 4 & & ,363 & & & ,666 & & & \\
\hline & 13 & & & & &, 755 & & & \\
\hline & 33 & & ,417 & & &, 722 & & & \\
\hline & 20 & ,465 & & ,359 & & & & & \\
\hline & 29 & & ,343 & & & ,649 & & & \\
\hline & \begin{tabular}{|l|} 
Eigen- \\
values
\end{tabular} & 6,341 & 4,623 & 3,148 & 2,717 & 1,570 & 1,483 & 1,302 & 1,190 \\
\hline & \begin{tabular}{|c|}
$\%$ \\
variancie
\end{tabular} & 15,852 & 11,558 & 7,871 & 6,793 & 3,926 & 3,706 & 3,254 & 2,974 \\
\hline
\end{tabular}


Ako sme spomínali, dôkazy konštruktovej validity sme získali pomocou dotazníkov PVQ, VISA a CMQ. Uvádzame výsledky korelácií príslušných škál s vybranými škálami.

Tab. 3 Korelácie subškál Dotazníka kariérovej orientácie a dotazníka PVQ (Portrait Values Questionnaire; Schwartz,2001) pri $n=265$

Legenda: Trad -Tradícia; Bezp. - Bezpečnost'; Konf. - Konformita; Sebaurč. - Sebaurčenie; Stimul. -

\begin{tabular}{|c|c|c|c|c|c|c|c|c|c|c|}
\hline Subškála & Trad. & Bezp. & Konf. & Sebaurč. & Moc & Úspech & Stimul. & Benev. & Univerz. & Hedoniz. \\
\hline Istota &, $206^{* * *}$ &, $429^{* * *}$ &, $215^{* * *}$ & $\begin{array}{c}-, 059 \\
D \\
\end{array}$ & - & - & \begin{tabular}{|c|}
,- 206 \\
D \\
\end{tabular} & - & - & $\begin{array}{c}, 830 \\
D\end{array}$ \\
\hline Autonómia & $\begin{array}{c}-, 081 \\
D \\
\end{array}$ & \begin{tabular}{|c|}
,$- \mathbf{1 7 0}^{* *}$ \\
$\mathrm{D}$ \\
\end{tabular} & $\begin{array}{c}-, 252 \\
\text { D }\end{array}$ &, $341^{* * *}$ & - & - &, $234 * * *$ & - & - &, $281^{* * *}$ \\
\hline \begin{tabular}{|c|} 
Manažérska \\
kompetencia
\end{tabular} & - & - & - & - &, $5^{2} 4^{* * *}$ &, $\mathbf{3 4 1}^{* * *}$ & - & $\begin{array}{c}, 038 \\
D \\
\end{array}$ & $\begin{array}{c}-, 113 \\
\mathrm{D}\end{array}$ & - \\
\hline \begin{tabular}{|c|} 
Technicko- \\
funkčná \\
kompetencia
\end{tabular} & - & - & - & - & $\begin{array}{c}-, 015 \\
D\end{array}$ & $\begin{array}{c}, 220^{* * *} \\
\quad \mathrm{D}\end{array}$ & ,136* &, $279 * * *$ &, $142 *$ & - \\
\hline $\begin{array}{c}\text { Služba } \\
\text { druhým }\end{array}$ & - & - & - & - & $\begin{array}{c}-, 400 \\
\text { D }\end{array}$ & $\begin{array}{l}243^{* * *} \\
\text { D }\end{array}$ &, $163^{* *}$ &, $\mathbf{2 8 3}^{* * *}$ &, $333^{* * *}$ & - \\
\hline Čistá výzva & $\begin{array}{c}, 029 \\
D \\
\end{array}$ & \begin{tabular}{|c|}
,$- 247 * * *$ \\
$D$ \\
\end{tabular} & $\begin{array}{c}051 \\
\mathrm{D}\end{array}$ & ,342*** & - &, $286^{* *}$ &, $271^{* * *}$ & - & - & ,001 \\
\hline Životný štýl &, $233^{* * *}$ & ,208** & ,036 & $\begin{array}{c}, 039 \\
\mathrm{D}\end{array}$ & - & - & $\begin{array}{c}-, 071 \\
D \\
\end{array}$ & - & - & $\begin{array}{c}, 035 \\
\text { D }\end{array}$ \\
\hline $\begin{array}{l}\text { Kreativita a } \\
\text { podnikanie }\end{array}$ & $\begin{array}{c}-081 \\
\text { D }\end{array}$ & $\begin{array}{c}, 059 \\
D\end{array}$ & $\begin{array}{c}-, 124 * \\
\text { D }\end{array}$ &, $193^{* *}$ & - &, $220^{* * *}$ & $269 * *$ & - & - & - \\
\hline
\end{tabular}

Stimulácia; Benev. - Benevolencia; Univerz. - Univerzalizmus; Hedoniz. - Hedonizmus; ${ }^{*} p<, 05$; ${ }^{* *} p$ $<, 01 ;{ }^{* * *} p<, 001 ; D-$ divergentná validita

Pozitívne korelácie dimenzie Istoty s dimenziami hodnôt konzervativizmu - Tradíciou, Bezpečnost'ou a Konformitou sú štatisticky významné. Tradícia a Konformita korelujú s dimenziou Istoty na nízkej úrovni - Tradícia $\mathrm{r}=, 206 ; \mathrm{p}<0,05$; Konformita $\mathrm{r}=215 ; \quad \mathrm{p}<0,01$. Stredne silný pozitívny vzt’ah bol zistený v súvislosti s dimenziou Bezpečia $\mathrm{r}=, 429 ; \mathrm{p}<0,01$. Vzt'ah s hodnotou Stimulácie je, ako sme očakávali negatívny, aj ked' slabší. Vzt'ahy kotvy Istoty so Sebaurčením a Hedonizmom ako predpokladané dôkazy divergentnej validity sa neukázali ako štatisticky významné.

Kotva Autonómie štatisticky významne pozitívne koreluje s dimenziou Sebaurčenia na strednej úrovni $\mathrm{r}=, 341 ; \mathrm{p}<, 01$. Podobne, pozitívne, avšak slabšie štatisticky významné vzt’ahy boli zistené s hodnotami Stimulácie a Hedonizmu. Ako dôkazy divergentnej validity - vzt'ahy s hodnotami Tradície a Konformity sa neukázali ako štatisticky významné. Vzt’ah s hodnotou Bezpečnosti však nadobúda očakávaný negatívny smer, je štatisticky významný, avšak slabý ( $\mathrm{r}=-, 170, \mathrm{p}<, 01)$.

Kotva Manažérskej kompetencie koreluje s hodnotou Moci štatisticky významne v stredne silných hodnotách $\mathrm{r}=, 554 ; \mathrm{p}<, 01$. S hodnotou Úspechu koreluje slabšie, avšak štatisticky významne $\mathrm{r}=, 341 ; \mathrm{p}<, 01$. Očakávané negatívne vzt'ahy s hodnotami Benevolencie a Univerzalizmu sme neidentifikovali ako štatisticky významné.

Kotva Technicko-funkčnej kompetencie koreluje pozitívne a štatisticky významne na nízkej úrovni s hodnotou Stimulácie. Podobne, ako sme očakávali, s kotvou Technicko-funkčnej kompetencie pozitívne korelujú hodnoty Benevolencie a Univerzalizmu, aj ked' ide o slabšie hodnoty. Očakávaná 
negatívna korelácia s hodnotou Moci nebola štatisticky významná. Taktiež očakávaná negatívna korelácia s hodnotu Úspechu bola štatisticky významná, avšak v opačnom - pozitívnom smere.

Kotva Služba druhým pozitívne štatisticky významne, avšak slabo koreluje s hodnotami Stimulácie, Benevolencie a Univerzalizmu. Očakávaná korelácia s hodnotou Moci sa ukázala ako štatisticky nevýznamná a korelácia s hodnotou Úspechu sa ukázala vo vzt'ahu ku kotve Služby druhým štatisticky významná, ale v opačnom smere.

Kotva Čistá výzva taktiež štatisticky významne, avšak slabo pozitívne koreluje s hodnotami Sebaurčenia, Úspechu a Stimulácie, nevýznamne však koreluje v prípade hodnoty Hedonizmu. Očakávaný vzt'ah kotvy Čistej výzvy sa v prípade hodnôt (1992) Tradície, Bezpečnosti a Konformity potvrdil iba v prípade hodnoty Bezpečnosti, vzt'ah bol však opät' slabší (r=,247, p<,001). Hodnoty Tradície a Bezpečnosti sa vo vzt'ahu ku kotve Čistá výzva neukázali ako významné.

Obdobne, kotva Kreativity a podnikania štatisticky významne, avšak slabo pozitívne koreluje s hodnotami Sebaurčenia, Úspechu a Stimulácie. Očakávané negatívne korelácie sú štatisticky významné, len v prípade vzt'ahu s hodnotou Konformity.

Tab. 4 Korelácie subškál Dotazníka kariérovej orientácie a dotazníkov VISA (Vocational Identity Status Assessment; Porfeli, 2011) a dotazníka CMQ (Career Motivation Questionnaire; Abele, Hausman, Weich, 1994), pri $n=265$

\begin{tabular}{|l|l|l|l|l|l|}
\hline \multicolumn{1}{|c|}{$\begin{array}{c}\text { Subškála/ } \\
\text { dimenzia }\end{array}$} & $\begin{array}{c}\text { Kariérový } \\
\text { záväzok } \\
\text { subškála }\end{array}$ & $\begin{array}{c}\text { Identif. s kar. } \\
\text { záväzkom }\end{array}$ & $\begin{array}{c}\text { Kariérový } \\
\text { záväzok } \\
\text { dimenzia }\end{array}$ & $\begin{array}{c}\text { Intrinzická } \\
\text { k. motivácia }\end{array}$ & $\begin{array}{c}\text { Extraprofesio- } \\
\text { nálna } \\
\text { k. motivácia }\end{array}$ \\
\hline $\begin{array}{l}\text { Technicko- } \\
\text { funkčná } \\
\text { kompetencia }\end{array}$ & $\mathbf{, 3 7 9 * *}$ & $\mathbf{, 2 9 7}^{* *}$ &, $\mathbf{3 8 8}^{* *}$ &, 037 & - \\
\hline Životný štýl & - & - & - & - &, $\mathbf{3 2 8}^{* *}$ \\
\hline
\end{tabular}

Legenda: ** $p<, 01$; Identif. s kar. záväzkom - Identifikácia s kariérovým záväzkom; Intrinzická k. motivácia - Intrinzická kariérová motivácia; Extraprofesionálna k. motivácia - Extraprofesionálna kariérová motivácia

Kotva Technicko-funkčnej kompetencie koreluje pozitívne a štatisticky významne, avšak na nižšej úrovni s dimenziou Kariérového záväzku a s prislúchajúcimi subškálami Identifikácie s kariérovým záväzkom a Kariérovým záväzkom.

Vzt’ah kotvy Technicko-funkčnej kompetencie a dimenzie Intrinzickej kariérovej motivácie sa neukázal ako štatisticky významný.

Kotva Životného štýlu štatisticky významne, pozitívne a slabšie koreluje s Extraprofesionálnou motiváciou. Pozitívne korelácie subškál Dotazníka pracovnej identity a subškál Dotazníka kariérovej orientácie sa ukázali ako slabšie a štatisticky významné. Výnimkou je štatisticky nevýznamný vzt’ah kotvy Technicko-funkčnej kompetencie a subškály Intrinzickej kariérovej motivácie. 


\section{DISKUSIA}

V rôznych štúdiách so vzorkami prevažne pracujúcich dospelých, ale aj absolventov vysokých škôl anglickej, americkej, filipínskej či izraelskej vzorky sa Cronbachov koeficient pohyboval pri n = 114-1847; $\alpha=, 56$ - ,91 (Steele, 2009). V porovnaní s našimi výsledkami, hodnoty nie sú také vysoké, avšak výsledky poukazujú na dobrú vnútornú konzistenciu, s výnimkou škál Technickofunkčnej kompetencie, Istoty a Životného štýlu.

Korigovaná položková analýza preukázala vhodnost' všetkých analyzovaných položiek okrem položky 17, ktorá bola problematická aj v rámci faktorovej analýzy. Z tohto faktu usudzujeme, že väčšina položiek v rámci daných škál spolu významovo súvisí.

Ako sme uvádzali v časti výsledkov, najlepším a konzistentným faktorovým riešením bolo osemfaktorové riešenie dotazníka, ktoré definoval pôvodne Schein (1978). Navrhované devät’faktorové riešenie, ako nad ním uvažujú niektorí autori (Marshall, Bonner, 2003; Danziger, Rachman-Moore, Valency, 2007) nevykázalo konzistentné výsledky. Faktor, ktorý pôvodne Schein definoval ako Kreativita a podnikanie sa javí ako obsahovo prepojený celok, ktorého obsah je vystavaný na spoločnom teoretickom základe (Schein ,1978).

V rámci škály Istoty sa problematicky javila položka 12, ktorá znela: „Nezostal by som v takej spoločnosti, ktorá by mi zadala úlohy ohrozujúce moju bezpečnost' pri práci“. Významovo sa teda odlišuje od ostatných položiek, ktoré sú sýtené príslušným faktorom. Ostatné položky škály poukazujú na istotu v zmysle bezpečia, ktoré práca ponúka v zmysle stability, v oblasti finančnej stability, či stability miesta, alebo aj stability v zmysle opaku pocitu slobody. Položka 12 však naráža na otázku bezpečnosti, ktorá ohrozuje samotnú bezpečnost' pri práci, čo sa väčšinou spája s fyzickou bezpečnost’ou. Korigovaná položková analýza tiež ukazuje, že daná položka so subškálou koreluje, avšak na nízkej úrovni $\mathrm{r}=, 158 ; \mathrm{p}<, 01$.

Problematickou položkou v rámci škály Autonómie je položka 38. Znenie položky: „Radšej by som z podniku odišiel/odišla ako by som mal/a akceptovat' prácu, ktorá by obmedzovala moju autonómiu a slobodu“ by malo odrážat' autonómne zmýšlajúceho človeka. Ukazuje sa však, že významovo položka môže narážat' na problematiku životného štýlu a trávenia času mimo pracovnej sféry, ked’že je tiež sýtená faktorom, ktorý prislúcha k položkám subškály Životný štýl, a to v stredných hodnotách. Vzhl'adom na rozdelenie kariérových kotiev podl'a Coetzeeovej (2011) kotvu Autonómie a kotvu Životného štýlu spája fakt, že obe kotvy sú založené na potrebách. Položková analýza však naznačuje akceptovatel'nú hodnotu korelácie položky so subškákou bez danej položky $\mathrm{r}=, 388 ; \mathrm{p}<, 001$.

Subškála Manažérskej kompetencie vykazuje vyššie nabitia položiek príslušným faktorom s výnimkou položky 2, ktorá sýti nekonzistentný 7. faktor. Znenie položky 2 je nasledovné: „V práci ma najviac napína to, ked' som schopný/á zapojit’ úsilie druhých $k$ splneniu spoločnej úlohy“. Vzhl'adom na obsah ostatných položiek, spadajúcich do 7 faktora, ide o zastávanie si svojej špecifickej funkcie v práci, ochotu riešit’ náročné úlohy v kombinácii s dodržiavaním bezpečnosti pri práci. Môžeme polemizovat', prečo sa položky združujú do významového celku. Delenie podl'a Coetzeeovej (2011) nám vysvetlenie neposkytuje, ked’že dané položky patria ku kotvám prislúchajúcim k rôznym kategóriám. Či ide o kombináciu autonómie s výkonovou zložkou osobnosti sa môžeme len domnievat'. Položka však viac spadá, podl'a našich výsledkov, do zmienenej oblasti, než do oblasti čisto manažérskej kompetencie, možno práve preto, že zahŕňa aj ostatných členov pracovného tímu. S ohl'adom na položkovú analýzu koreluje so samotnou škálou v nízkych hodnotách $\mathrm{r}=, 133 ; \mathrm{p}<, 05$.

Položky škály Technicko-funkčnej kompetencie pôsobia problematicky. Prvá položka v znení: „Chcem byt' taký/á dobrý/á v tom čo robím, aby druhí vždy vyhl'adávali moju odbornú radu," sýti 1. faktor v stredných hodnotách, a tiež 8 . faktor v stredných hodnotách v zápornom smere. 1. 
faktor je sýtený položkami Čistej výzvy, a tiež položkami Služby druhým. Obe kotvy spadajú do kategórie na hodnoty zameraných kotiev. Obsahovo sa môže v položke presadzovat' význam, ktorý zdôrazňuje sociálne okolie - vyhl'adávanie rád druhými (čo by vysvetl'ovalo významový ráz položky vzhl'adom k subškále Služba druhým). Položková analýza ukázala slabý vzt'ah položky so škálou $r=, 188 ; p<, 01$. Okrem nezrovnalostí vo faktorovej a položkovej analýze, ani interná konzistenciu škály nepovažujeme za dostatočnú - $\alpha=, 494$ (tab. 1). Položka 9 sýti taktiež prvý faktor. Položka znie: „Vo svojom zamestnaní sa budem cítit’ úspešný/á len vtedy, ak budem môct' neustále rozvíjat’ a zlepšovat' svoje schopnosti“. Významovo môže táto položka spadat' k obsahu subškály Čistá výzva, ked’že do popredia môže vystupovat' práve neustále rozvíjanie a zlepšovanie schopností. Položka so škálou však koreluje stredne silne $r=, 409 ; p<, 001$. Položka 17 v znení: „Pre mňa je lákavejšie stat’ sa vrcholovým funkčným alebo technickým manažérom vo svojom odbore ako generálnym riaditel’om," tiež štatisticky nevýznamne koreluje so škálou a silne sýti ôsmy faktor. Položka 26 sýti v stredných hodnotách siedmy faktor, ktorý je zastúpený položkami, ktoré vypovedajú o zastávaní špecifickej funkcie v práci, o ochote riešit’ náročné úlohy v kombinácii s dodržiavaním bezpečnosti pri práci. Toto zistenie korešponduje aj so znením položky, ktorá znie „Radšej by som odišiel/odišla zo spoločnosti v ktorej pracujem, než by som prijal/a preloženie a rekvalifikáciu, ktorá by ma odlúčila od oblasti mojej profesie“. Položka so škálou koreluje na nižšej úrovni $\mathrm{r}=, 311 ; \mathrm{p}<, 001$. Položka sýti prvý faktor, faktor Služby druhým a Čistej výzvy. S ohl'adom na znenie položky: „Moja práca ma napíňa najviac vtedy, ked’ som schopný/á využit' svoje špeciálne zručnosti a talent," by malo íst' zjavne o položku, ktorá sýti faktor Technicko-funkčnej kompetencie. Podl'a našich výsledkov sa znova ukazuje neschopnost’ položiek významovo rozlíšit' faktor Čistej výzvy, Služby druhým a Technicko-funkčnej kompetencie. Položky môžu individuálne jednotlivcovi zdôrazňovat' istú čast' významu, a teda sa vo výsledkoch faktorovej analýzy nedokážu samostatne presadit's jasným významom.

Subškála Služba druhým sýti prvý faktor a podl’a našich výsledkov sa javí ako jednotná. Problematickým však je fakt, že prvý faktor je jednotne sýtený položkami viacerých subškál, a to narúša konzistentnost’ škály.

V subškále Čistá výzva, je problematickou položka 32. Znenie položky: „Dávam prednost” pracovným príležitostiam, ktoré predstavujú silnú výzvu pre moju schopnost' riešit' problémy a moju sút’aživost'," významovo predstavuje nielen výzvu, ale s ohl'adom na výsledky tiež aj dôležitú vlastnost' spadajúcu do oblasti manažérskych kompetencií. Položková analýza ukázala však stredne silný korelačný koeficient položky s danou subškálou r=,540 pri p<,01.

Čistá výzva a Služba druhým sú kotvy, ktoré sú zaradené do kategórie- kotvy založené na hodnotách. Na jednej strane sa ukazuje v pozitívnom slova zmysle význam definovania danej kategórie, na strane druhej sa však podl'a výsledkov faktorovej analýzy k zmieneným kotvám pripája faktor Technicko-funkčnej kompetencie, ktorý zas podl'a Wilsovej, Wilsa a Trebleyho (2010) spolu s kotvou Služba druhým spadá do kvadrantu, ktorý identifikoval pôvodne vo svojej Kruhovej teórii hodnôt Schwartz - a to do kvadrantu Sebatranscendencie. Na základe týchto skutočností dáva zmysel to, že sa dané tri faktory zlučujú do jedného. Na druhej strane však by mali byt' položky daných faktorov natol'ko významovo odlíšené, aby vytvárali vlastné faktory.

Subškála Životného štýlu sa javí ako konzistentná z pohl'adu sýtenia položiek daným faktorom. Podobne konzistentne sa javí aj subškála Kreativita a podnikanie s výnimkou položky 20: „Pocit'ujem najväčšiu spokojnost' vtedy, ked' dokážem vytvorit' niečo, čo je primárne výsledkom mojich zručností a môjho úsilia," môže významovo spadat' skôr do obsahu subškály Technickofunkčnej kompetencie, ked’že je sýtená najmä prvým faktorom. V rámci položkovej analýzy položka slabo koreluje s danou subškálou $r=, 132 ; \mathrm{p}<, 05$.

Z výsledkov je zrejmé, že nie všetky očakávané vzt’ahy subškál Dotazníka kariérovej orientácie so subškálami dotazníka PVQ sú štatisticky významné. Aj ked' väčšina očakávaných vzt'ahov 
vykazuje očakávané výsledky, vzt’ahy sú skoro vo všetkých štatisticky významných vzt'ahoch slabšie. Vzt’ahy však vo väčšine prípadov nadobúdali očakávaný smer, opačný smer očakávaných vzt'ahov nastal v prípade dôkazov divergentnej validity kotiev Technicko-funkčnej kompetencie, Službe druhým a Čistej výzvy (tab. 3). Čo sa týka očakávaných korelácií subškál Dotazníka kariérovej orientácie a dotazníka VISA a CMQ všetky očakávané vzt'ahy s výnimkou očakávanej štatisticky významnej pozitívnej korelácie subškály Intrinzickej kariérovej motivácie a kotvy Technicko- funkčnej kompetencie sú štatisticky významné, aj ked’ slabšie (tab. 4).

\section{ZÁVER}

Faktorová štruktúra dotazníka sa v zahraničných štúdiách pohybovala v širokom rozmedzí 3 - 11 faktorov. Vnútorná konzistencia dotazníka sa pohybovala od $\alpha=, 56$ - ,93. Test-retestová reliabilita nadobúdala rozmanité hodnoty, a to $\mathrm{r}=, 38-, 92 ; \mathrm{p}<, 05$. Validita bola označovaná ako akceptovatel'ná až dobrá (Danziger, Rachman, Moore, Valency, 2008; Steele, 2009). Nástroj sa vo svete teda považuje za všeobecne psychometricky akceptovatel'ný (Coetzee, Schreuder, 2009).

Cronbachov koeficient $\alpha$ si v rámci našich analýz škál dotazníka zachoval uspokojivé hodnoty s výnimkou škál Istoty $\alpha=, 610$; Životného štýlu $\alpha=, 677$; a Technicko-funkčnej kompetencie $\alpha=, 494$. V prípade, že sa jedná o osobnostný dotazník, je podl'a Trauba (1994) akceptovatel'ná úroveň Cronbachovej alfy $\alpha=, 60-, 70$, podl'a iných autorov je však akceptovatel'ná úroveň až $\alpha>, 70$ (Tavakol, Dennick, 2011). Na základe prevedenia faktorovej analýzy dotazníka sa nemôžeme s istotou vyjadrit' o vhodnosti osemfaktorového modelu dotazníka, avšak nemôžeme ho ani zavrhovat'. Na základe našich dát sa tiež nemôžeme priklonit' k názoru niektorých autorov (Marshall, Bonner, 2003; Danziger, Rachman-Moore, Valency, 2007), že dotazník pozostáva z deviatich faktorov. Samotná nevýhoda metódy - exploračnej faktorovej analýzy je tá, že má tendenciu položky zhlukovat' do niekol'kých prvých faktorov, teda zlučovanie faktorov a malé percento variancie, ktoré vyčerpávajú najmä siedmy a ôsmy faktor, nám nemusia udávat' vyčerpávajúci pohl'ad na faktorovú štruktúru dotazníka.

Faktorová štruktúra dotazníka obsahuje viac položiek, ktoré viac sýtia neprislúchajúce faktory (ako napr. položky 2, 12, 38 a položky subškály Technicko-funkčnej kompetencie, ktorá je zjavne nekonzistentná; tab. 1) Ako sme vo výsledkoch tiež zmieňovali, štruktúra dotazníka nie je schopná rozlišovat' medzi položkami subškál Technicko-funkčnej kompetencie, Služby druhým a Čistej výzvy. Aj preto faktory 7 a 8 neobsahujú položky, ktoré sú faktormi podstatne sýtené a nevytvárajú komplexný celok. Dôvody zlúčenia faktorov subškál Čistá Výzva a Služba druhým sme sa pokúsili, v rámci diskutovania výsledkov interpretovat' pomocou Coetzeeovej kategorizáciu kariérových kotiev (2011), ked’že obe kotvy spája ich podstata, ktorá sa odvíja od hodnotovej orientácie jednotlivca.

Korigovaná korelácia položiek si zachováva prevažne stredne silné až silné hodnoty korelačných koeficientov s výnimkou problematickej položky 17 zo škály Technicko-funkčnej kompetencie $(\mathrm{r}=, 312 ; \mathrm{p}<, 05-\mathrm{r}=, 741 ; \mathrm{p}<, 001)$. Výsledky naznačujú, že by mohlo íst' o validný merací nástroj. Aj ked' sme si vedomí, že vo väčšine prípadov sú korelačné koeficienty nižšie než sme očakávali ( $\mathrm{r}=-$ ,124; p<,05 - r=,429; p<,001; tab. 3, tab. 4). Vo väčšine skúmaných vzt'ahov sa ukázali štatisticky významné vzt’ahy. Korelácie tiež nadobúdali vo väčšine prípadov očakávaný smer.

Vzhl'adom na rozporuplné výsledky je potrebné podporit' naše zistenia dodatočným výskumom na inej vzorke. $V$ d'alšom výskume sa odporúčame zamerat' na test-retestovú validitu nástroja, ked'že sme nemali možnost' merania zopakovat'. Alternatívou môže byt' prístup s pokusom o preformulovanie problematických položiek namiesto ich vylúčenia, spôsobom, aby bola zdôraznená ich významová zložka. Odporúčame prihliadat' na špecifiká skúmaného dotazníka, ktoré sa v tejto práci ukázali ako nezanedbatel'né. Zároveň odporúčame dotazník d'alej používat' na výskumné účely, a to najmä v oblasti kariérového poradenstva. 


\section{LITERATÚRA}

Abele, A. E., Hausmann, A., \& Weich, M. (1994). Karriereorientungen angehender Akademikerinnen und Akademiker. Kleine Verlag.

Avallone, F., Farnese, M. L., Pepe, S., \& Vecchione, M. (2010). The Work Values Questionnaire (WVQ): Revisiting Schwartz's Portrait Values Questionnaire (PVQ) for work contexts. BPA-Applied Psychology Bulletin (Bollettino di Psicologia Applicata).

Baňasová, K. (2016). Využitie Teórie kognitívneho spracovania informácií v oblasti kariérového poradenstva druhej smerovej vol'by, Dizertačná práca. Nitra: UKFv Nitre.

Baňasová, K., \& Sollár, T. (2015). Psychometrické vlastnosti Dotazníka kariérovej motivácie. Psychometric qualities of the Career Motivation Questionnaire. PhD existence 2015, 117.

Baňasová, K., Sollár, T., \& Sollárová, E. (2015). Values and Career Motivation in the context of Vocational Identity. In InPACT 2015: International Psychological Applications Conference and Trends. Proceedings from International Conference, Ljubljana, Slovenia 2. - 4. May 2015 (pp. 315317). Lisbon, Portugal: World Institute for Advanced Research and Science.

Brindle, L., \& Whapham, J. (2003). How bona fide is Schein's Career Anchors questionnaire? Selection and Development Review, 19(1), 10-14.

Buddeberg-Fischer, B., Stamm, M., Buddeberg, C., \& Klaghofer, R. (2008). The new generation of family physicians-career motivation, life goals and work-life balance. Swiss Medical Weekly, 138(21-22), 305-312.

Budjačová, R. (2015). Kariérové ukotvenie vo vzt'ahu k teórii hodnotových typov, Diplomová práca. Nitra: Univerzita Konštantína Filozofa v Nitre.

Coetzee, M. (2012). Archetypal life themes, career orientations, and employability satisfaction of higher education students: A postmodern career counselling perspective. South African Journal of Higher Education, 26(1), 691-716.

Coetzee, M., \& Schreuder, D. (2009). Using the Career Orientations Inventory (COI) for measuring internal career orientations in the South African organisational context. SA Journal of Industrial Psychology, 35(1), 99-111.

Coetzee, M., \& Schreuder, D. (2011). The relation between career anchors, emotional intelligence and employability satisfaction among workers in the service industry. Southern African Business Review, 15(3), 76-97.

Costigan, R., Gurbuz, S., \& Sigri, U. (2016). Schein's Career Anchors: Testing Factorial Validity, Invariance Across Countries, and Relationship With Core Self-Evaluations. Journal of Career Development.

Crepeau, R. G., Crook, C. W., Goslar, M. D., \& McMurtrey, M. E. (1992). Career anchors of information systems personnel. Journal of Management Information Systems, 9(2), 145-160.

Crocetti, E., Schwartz, S. J., Fermani, A., \& Meeus, W. (2010). The Utrecht-Management of Identity Commitments Scale (U-MICS). European Journal of Psychological Assessment.

Custodio, L. P. (2000). Career anchors of Filipino academic executives. School of Commerce, Flinders University of South Australia.

Danziger, N., Rachman-Moore, D., \& Valency, R. (2008). The construct validity of Schein's career anchors orientation inventory. Career Development International, 13(1), 7-19.

DeLong, T. J. (1982). Re-examining the career anchor model. Brigham Young University. 
Feldman, D. C., \& Bolino, M. C. (1996). Careers within careers: Reconceptualizing the nature of career anchors and their consequences. Human Resource Management Review, 6(2), 89-112.

Field, A. P. (2005). Discovering Statistics using SPSS. London: Sage.

Furnham, A., Forde, L., \& Ferrari, K. (1999). Personality and work motivation. Personality and individual differences, 26(6), 1035-1043.

Gallová, L'. (2013). Centrum pedagogicko-psychologického poradenstva- nepubl. interview.

Hendl, J. (2006). Přehled statistických metod zpracování dat. Praha:Portál.

Hoyle, R. H. (2012). Handbook of Structural Equation Modeling. New York: Guilford Press.

Igbaria, M., \& Baroudi, J. J. (1993). A short-form measure of career orientations: A psychometric evaluation. Journal of Management Information Systems, 10(2), 131-154.

Igbaria, M., Greenhaus, J. H., \& Parasuraman, S. (1991). Career orientations of MIS employees: An empirical analysis. MIS Quarterly, 15, 151-169. doi:10.2307/249376.

Ihnacík, J. (2013). Centrum pedagogicko-psychologického poradenstva- nepublikované interview. Ihnacík, J., Špitka, J., \& Paulová, M. (2007). Projekt „Úspech nosíme v sebe“ - ovplyvňovanie kariérneho vývinu študentov stredných škôl so špecifickými poradenskými potrebami a ich uplatnenie na trhu práce. In J. Ihnacík, a kol. (Eds.), Kariérové poradenstvo na stredných školách (s. 4-17). Košice: PPP pre SŠ.

Jiang, J. J., \& Klein, G. (1999). Supervisor support and career anchor impact on the career satisfaction of the entry-level information systems professional. Journal of management information systems, 16(3), 219-240.

Kaiser, H. (1974). An index of factorial simplicit. Psychometrika, 39 (1), 31-36.

Kluckhohn, C. (1951). Values and value-orientations in the theory of action: An exploration in definition and classification.

Kohn, M. L., \& Schooler, C. (1983). Work and personality: An inquiry into the impact of social stratification. Ablex Pub.

Lepeňová, D. (2006). Kariérové poradenstvo v školstve na Slovensku. Bratislava: Výskumný ústav detskej psychológie a patopsychológie a Metodicko-pedagogické centrum. Retrieved from http://www. poradnakk. sk/joomla/images/.../Karierove.../Kar-por_vych-por. doc.

Luyckx, K., Goossens, L., Beyers, W., \& Soenens, B. (2006). Brief report: The ego identity process questionnaire: Factor structure, reliability, and convergent validity in Dutch-speaking late adolescents. Journal of adolescence, 29(1), 153-159.

Marcia, J. E. (1993). The status of the statuses: Research review. In J. E. Marcia et al. Ego identity (pp. 22-41). Springer: New York.

Marshall, V., \& Bonner, D. (2003). Career anchors and the effects of downsizing: implications for generations and cultures at work. A preliminary investigation. Journal of European Industrial Training, 27(6), 281-291.

Meeus, W. (1996). Studies on identity development in adolescence: An overview of research and some new data. Journal of youth and adolescence, 25(5), 569-598.

Porfeli, E. J. (2011). Vocational Identity Status Assessment (VISA). 3.

Porfeli, E. J., Lee, B., Vondracek, F. W., \& Weigold, I. K. (2011). A multi-dimensional measure of vocational identity status. Journal of Adolescence, 34(5), 853-871.

Ramakrishna, H., \& Potosky, D.(2003). Conceptualization and exploration of composite career anchors: Ananalysis of information systems personnel. Human Resource Development Quarterly, 14(2), 199-214. doi:10.1002/hrdq.1060. 
Shein, E. (1990). Career Anchors: Discovering Your Real Values. San Diego, CA: Pfeiffer \& Company. Shein, E.H. (2004). Kariérové kotvy. Co považujete za skutečně důležité. DBM.

Schein, E. H. (1978). Career dynamics: Matching individual and organizational needs. Reading, MA: Addison-Wesley.

Schein, E. H. (1996). Career anchors revisited: Implications for career development in the 21st century. The Academy of Management Executive, 10(4), 80-88.

Schein, E. M. (2004). Organizational culture and leadership (3rd. ed.). Jossy-Bass.

Schwartz, S. H. (2001). A proposal for measuring value orientation across nations. In The European social survey core questionnaire development (pp. 241-296). ESS central co-ordinating team.

Schwartz, S. H. (2012). An Overview of the Schwartz Theory of Basic Values. Readings in Psychology and Culture, 2(1).

Steele, C. (2009). Measuring Career Anchors and Investigating the Role of Career Anchor Congruence, Doctoral dissertation. University of Coventry and University of Worcester.

Stevens, J. (2002). Applied Multivariate Statistics for the Social Sciences (4th ed.). Mahwah, NJ: Lawrence Erlbaum Associates.

Stevens, J. (2002). Applied Multivariate Statistics for the Social Sceinces (4th ed.). Mahwah, NJ: Lawrence Erlbaum Associates.

Šnejdrlová, R. (2015). Interpersonálne problémy vo vzt'ahu k hodnotám, Bakalárska práca. Nitra: Univerzita Konštantína Filozofa v Nitre.

Tavakol, M., \& Dennik, R. (2011). Making sense of Cronbach's alpha. International Journal of Medical Education, 2, 53-55.

Wils, L., Wils, T., \& Tremblay, M. (2010). Toward a career anchor structure: An empirical investigation of engineers. Relations industrielles/Industrial relations, 65(2), 236-256.

\section{Psychometric properties of career orientations inventory}

Abstract: Background: The study focuses on the Career Orientation Inventory which identifies career anchors according to Schein.

Aim of the study: Aim of the study is to analyze the psychometric properties of the questionnaire.

Methods: The sample consists of 265 high school students. We used Cronbach's $\alpha$, corrected item-total correlations and exploratory factor analysis. The construct validity was analysed by questionnaires VISA (Porfeli, 2011); PVQ (Schwartz, 2001) and CMQ (Abele, Hausman, Weich, 1994).

Results: The eight-factor questionnaire was applying. The results indicate it could be a valid measuring tool, but we discussed specific problematic items.

Implications: We recommend taking into account the specifics of the questionnaire. We recommend using the questionnaire for research purposes.

Key words: Career Orientations Inventory, career anchors, reliability, construct validity, exploratory factor analysis 
Grantová podpora:

Príspevok vznikol ako súčast' riešenia grantových projektov APVV-0540-12 - Psychometrická kvalita psychodiagnostických nástrojov v kariérovom poradenstve a UGA IX/2/2017 Kariérové poradenstvo druhej smerovej vol'by a využitie faktorov Teórie kognitívneho spracovania informácií v poradenskom procese. 